\title{
Establishment of Cryptostegia madagascariensis in the semiarid: what is the role of abiotic factors in germination and initial growth?
}

\author{
Potencial invasor de Cryptostegia madagascariensis no semiárido: qual o papel dos fatores \\ abióticos na germinação e crescimento inicial? \\ S. F. de Brito ${ }^{*}$; C. L. Pinheiro ${ }^{2}$; D. M. da S. Matos ${ }^{3}$; S. Medeiros Filho ${ }^{2}$ \\ ${ }^{1}$ Universidade Estadual do Ceará, 60714-903, Fortaleza-CE, Brasil \\ ${ }^{2}$ Departamento de Fitotecnia, Universidade Federal do Ceará, 60020-181, Fortaleza-CE, Brasil \\ ${ }^{3}$ Departamento de Hidrobiologia, Universidade Federal de São Carlos, 13565-905, São Carlos-SP, Brasil \\ *selma.brito@uece.br \\ (Recebido em 03 de maio de 2020, aceito em 02 de maio de 2021)
}

\begin{abstract}
Studies on seed germination and seedling development in different environmental conditions help to understand the ability of exotic species to colonize new environments. Cryptostegia madagascariensis is an exotic invasive species in the semiarid Caatinga Phytogeographical Domain, in the northeastern region of Brazil. In this study, was evaluate how the abiotic factors interfere in germination and the impacts of a water deficit in the initial growth of seedlings. During germination, the seeds were exposed to different temperatures (constant and alternating) combined with two light conditions (white and dark light). In germination, we also evaluated the effects of water and saline stress. In initial growth, the seedlings were submitted to four levels of water availability $(100 \%, 70 \%, 40 \%$ and $10 \%$ of field capacity). The milder ( 20 at $30^{\circ} \mathrm{C}$ ) and alternate temperatures studied provided greater germination four days after sowing, independent of light. High temperatures $\left(35^{\circ} \mathrm{C}\right)$ are a limiting factor for germination, as well as water and saline stress $(>2$ $\mathrm{MPa}$ ). The water deficit reduces the growth of the seedlings, but these showed morphological adaptations to the different treatments. However, lower levels of water reduced its invading potential. Therefore, factors such as high temperature $\left(>30^{\circ} \mathrm{C}\right)$, saline and water stress, reduce its germination potential and the reduction of water availability affects its growth, but not its survival.
\end{abstract}

Keywords: Biological invasion, germination of seeds, seedling establishment.

Estudos sobre germinação de sementes e desenvolvimento de plântulas em diferentes condições ambientais ajudam a entender a capacidade de espécies exóticas colonizarem novos ambientes. Cryptostegia madagascariensis é uma espécie exótica invasora no domínio fitogeográfico da Caatinga, região semiárida do Nordeste do Brasil. Neste estudo, foi avaliado como os fatores abióticos interferem na germinação e os impactos do déficit hídrico no crescimento inicial de mudas. Durante a germinação, as sementes foram expostas a diferentes temperaturas (constante e alternada), combinadas com duas condições de luz (luz branca e escura). Na germinação, também foram avaliados os efeitos do estresse hídrico e salino. No crescimento inicial, as mudas foram submetidas a quatro níveis de disponibilidade de água $(100 \%, 70 \%, 40 \%$ e $10 \%$ da capacidade de campo). As temperaturas mais amenas $\left(20\right.$ a $\left.30^{\circ} \mathrm{C}\right)$ e alternadas estudadas proporcionaram maior germinação quatro dias após a semeadura, independente da luz. Altas temperaturas $\left(35^{\circ} \mathrm{C}\right)$ são um fator limitante para a germinação, assim como o estresse hídrico e salino (>2 MPa). O déficit hídrico reduz o crescimento das mudas, porém estas apresentaram adaptações morfológicas aos diferentes tratamentos. No entanto, níveis mais baixos de água reduziram seu potencial invasor. Portanto, fatores como alta temperatura $\left(>30^{\circ} \mathrm{C}\right)$, estresse salino e hídrico reduzem seu potencial de germinação e a redução da disponibilidade de água afeta seu crescimento, mas não sua sobrevivência.

Palavras-chave: Invasão biológica, germinação de sementes, estabelecimento de plântulas.

\section{INTRODUCTION}

Invasive species cause impacts at different scales, altering soil properties, reproductive potential and thus causing losses in biological diversity $[1,2]$. Therefore, studies are needed to investigate the ecological factors and inherent characteristics of each species that affect the naturalization process in new communities [3]. Thus, it is known that the invasiveness of exotic species may be 
associated with a number of characteristics, such as reproduction [4], phenotypic plasticity [5], and ability to colonize low resource environments [6].

Studies on seed germination and emergence of seedlings are important tools to help understanding the potential for colonization of exotic species in introduced areas [7], the optimal conditions for germination are generally similar to those required for growth [8]. In addition, seed germination is a key event for the propagation of species and can be regulated by environmental factors such as temperature, light, salinity, and soil moisture [9].

After germination, the success of an invasive species in different environmental conditions is also related to its ability to utilize limited resources efficiently [10]. In arid and semi-arid regions, rains occur irregularly and are alternated by periods of drought [6], making water availability one of the main limiting factors for the establishment of new species in these regions $[6,11]$. Thus, in many arid regions exotic species invade areas of higher water availability [12]. Studies regarding invasive plants that occur in riparian or flooded areas of dry regions, show that these species are able adapt to the reduction in water availability $[13,14]$.

However, for some species the reduction of water availability may have direct effects on invasiveness, as it reduces growth and productivity [15, 16]. Morais e Freitas (2012) [16], showed that moderate water stress did not severely affect the invasive Acacia longifolia (Andrews) Willd, but reduces growth and affects the physiological traits, which may limit the invasion of this species in an area of low water availability. In climbing plants, one of the groups that cause the most impacts, invasiveness is associated with rapid growth, so they tend to settle in areas of high humidity, such as riparian areas [17].

Cryptostegia madagascariensis Bojer ex Decne. (Apocynaceae) is a scandent shrub native to Madagascar (Africa), where it occurs in dry forests, disturbed areas, and river banks, growing as a shrub or as a climbing plant [18]. In the northeastern region of Brazil, it has become an invasive species, establishing dense populations mainly in areas near rivers [19]. One of the characteristics of this species is to produce many seeds in a single reproductive event which are dispersed by wind and germinate in great quantity [20]. One of the areas most invaded by C. madagascariensis in Brazil are the riverine "carnaubais" [19], areas characterized by high water availability part of the year and the conspicuous presence of the endemic palm Copernicia prunifera (Mill.) H. E. Moore, known as carnauba [21].

Therefore, understanding how abiotic factors (e.g., temperature, light, water, and saline stresses) affect germination and how water availability, the most limiting factor for the establishment of seedlings in dry regions [6], interferes with its initial growth may help to understand the characteristics that enable $C$. madagascariensis to invade the Brazilian semiarid regions. Additionally, this will help identify areas most susceptible to invasion and trace control strategies based on the factors that promote their establishment.

Our hypotheses are that: I- C. madagascariensis presents high germination rates, tolerating a wide range of temperatures; II- The availability of light increases its germination, as it is a species that invades mainly disturbed areas; III- Reduced water availability negatively affects the germination and its potential for invasion, as higher water availability environments concentrate the invaded areas. Thus, our objectives were to evaluate how abiotic factors interfere in germination and the impacts of a water deficit in the initial growth of seedlings of the invasive $C$. madagascariensis.

\section{MATERIALS AND METHODS}

\subsection{Seed Collection}

The seeds used in the experiment were collected at the Experimental Farm Vale do Curu, (latitude $3^{\circ} 49^{\prime} 25^{\prime \prime} \mathrm{S}$; longitude $39^{\circ} 20^{\prime} 20^{\prime \prime} \mathrm{W}$ ) which belongs to the Federal University of Ceará (UFC) and is located in Pentecoste County, Ceará State, Brazil. This farm is located in the Brazilian semiarid region with annual rainfall of $772.2 \mathrm{~mm}$ (local weather station). After collection, we packed the fruits in plastic bags that were transported to the Seeds Laboratory of the UFC. We collected plant material from this farm and took it to be identified by specialists the Herbarium Prisco Bezerra - EAC UFC and deposited under record number 54608 (EAC). 


\subsection{Germination}

We evaluated germination at different temperatures, light conditions, and under water and saline stresses, through two experiments. In the first, we evaluated germination at different temperatures and light conditions. We used temperatures ranging from 20 to $40^{\circ} \mathrm{C}$, constant $(20,25,30,35$, and $\left.40^{\circ} \mathrm{C}\right)$ and alternating $\left(20 / 25,20 / 30\right.$ and $\left.20 / 35^{\circ} \mathrm{C}\right)$. Each temperature was combined with two light conditions: white and continuous dark, totaling 16 treatments, in a factorial arrangement in a completely randomized design ( 8 temperatures $\times 2$ light). Constant temperatures we used 12/12 hours of light and dark, and for alternating temperatures, 12 hours of light corresponding to the highest temperature (day) and 12 hours of dark were used for the lowest temperature (night). In the absence of light, the Petri dishes were wrapped in aluminum foil and packed in a black plastic bag.

In each treatment, four replicates of 25 seeds were used, distributed in Petri dishes containing two sheets of 'germitest' paper as substratum, moistened with $3.5 \mathrm{ml}$ of distilled water. The seeds were placed in germination chambers of the type B.O.D. and evaluations were performed daily for 10 days after sowing. Treatment dark the seeds were evaluated with green light of safety. A protruded radicle was the criterion established for the seeds to be considered germinated. On the tenth day, we calculated the germination (\%) and the average germination time [22].

In the second experiment, we simulated water and salt stresses during germination using an osmotic solution of polyethylene glycol (PEG 6000) and sodium chloride $(\mathrm{NaCl})$, respectively. The solution of water stress was prepared according to the methodology described by Michel e Kaufmann (1973) [23], and for the salt stress the van't Hoff equation was used [24]. We used concentrations of $-0.2,-0.4,-0.6,-0.8$, and $-1.0 \mathrm{MPa}$ for each of the stress treatments, besides the concentration of 0.0 referring to control treatment where we used only distilled water.

Thus, in this experiment seeds were submitted to six water stress treatments and six salt stress treatments with four replicates of 25 seeds each treatment. The substrate was moistened with 3.5 $\mathrm{ml}$ of the solution corresponding to each treatment. The substrate was moistened with $3.5 \mathrm{ml}$ of the solution corresponding to each treatment and were placed in germination chambers at $25^{\circ} \mathrm{C}$ with a photoperiod of 12/12 hours of light and dark.

After 15 days of evaluation the seeds that did not germinated in the stresses evaluated were transferred to Petri dishes moistened with distilled water and evaluated for a further 10 days to verify the ability to recovery after a period under stress conditions, according to Gorai et al. (2009) [25]. With the obtained data, we calculated germination (\%), mean germination time, and germination recovery $(\%)$.

\subsection{Initial growth in water deficit}

The seedlings for the experiment were produced after sowing in trays containing soil and humus (3: 1 ratio). After 30 days, 160 seedlings were randomly selected and transplanted to $32 \mathrm{~cm}$ high pots containing $8 \mathrm{~kg}$ of soil, standardized by weighing. The soil used in the experiment was previously dried open air, sieved, and determined the field capacity (FC) through the amount of water retained by the soil after saturation and natural drainage according to Souza et al. (2000) [26]. Water retention in $8 \mathrm{~kg}$ of soil was $1.4 \mathrm{~L}$, determined as $100 \%$ of the field capacity. A water availability gradient was simulated with four levels: absence of stress (100\% of FC), low stress ( $70 \%$ of FC), moderate stress ( $40 \%$ of FC), and severe stress ( $10 \%$ of FC).

The pots were arranged in four replicates, 10 plants for each treatment arranged in a completely randomized design. The seedlings underwent a period of acclimatization, during which for two days they continued to receive $100 \%$ of the $\mathrm{FC}$ and then started to receive water levels according to each treatment. To maintain the four water levels, eight vessels of each treatment was weighed every other day and the lost volume supplemented. During the experiment, the temperature and relative humidity was monitored by means of a thermohygrometer with a maximum temperature of $37.1^{\circ} \mathrm{C}$ and a minimum of $24.2^{\circ} \mathrm{C}$, and a mean ambient relative humidity of $63.5 \%$.

At 75 days, morphological measurements of the plants of each treatment were taken to verify the effects of water stress. Initially the following variables were measured: height, diameter of the stem base, and number of leaves. Then, the plants were removed from the pots using running water and the length of the root was measured and also measured the total leaf area. The plants were 
divided in leaves, stems, and roots and placed in the drying oven at $80^{\circ} \mathrm{C}$ for 48 hours to determine the dry mass. With the data obtained, we calculated the specific leaf area (SLA), root / shoot mass ratio (R/S ratio), relative growth rate (RGR) [27], and root specific growth (RSG) [28] for each treatment.

\subsection{Data analysis}

Analyzed the temperature $\times$ light interaction data using a two-way ANOVA. The salt and water stress variables in the germination was analyzed through a simple ANOVA. To use the ANOVA, we tested the normality and homogeneity of the data through the Kolmogorov-Smirnov and Levene tests, respectively.

The germination data when not normal was transformed into sine $\operatorname{arc} \sqrt{\mathrm{X}} / 100$. The means were compared by the Tukey test at $5 \%$ probability. The effects of water stress on the seedlings were analyzed by ANOVA. Data that were not normal were transformed by $\log (\mathrm{x}+1)$. The means were compared by the Tukey test at 5\% probability. Finally, we performed a regression analysis among the variables related to growth: leaf area, total dry mass, and RGR. All statistical Analyses and graphs was performed using software Sigma Plot 12.00 and Assistat.

\section{RESULTS}

\subsection{Germination}

The interaction between temperature and light had a significant effect only on the percentage of germinated seeds $(\mathrm{p}<0.05)$. Only temperature significantly affected average germination time $(\mathrm{p}$ $<0.01$ ). The highest percentages of germination, approximately $90 \%$, occurred at the constant temperatures of 20 and $25^{\circ} \mathrm{C}$ and at alternating temperatures $20 / 25,20 / 30$ and $20 / 35^{\circ} \mathrm{C}$. However, at $35^{\circ} \mathrm{C}$, germination was less than $10 \%$ and at $40^{\circ} \mathrm{C}$ there was no germination. The seeds do not depend on light to germinate, although under temperatures of 25 and $30^{\circ} \mathrm{C}$ and dark continuous caused a reduction in germination (Figure 1a). Was observed that at $25,20 / 25$, and $20 / 30^{\circ} \mathrm{C}$, most of the seeds germinated until the fourth day. Alternatively, at temperatures of 20,30 , and $35^{\circ} \mathrm{C}$, the germination time was seven days (Figure 1b).
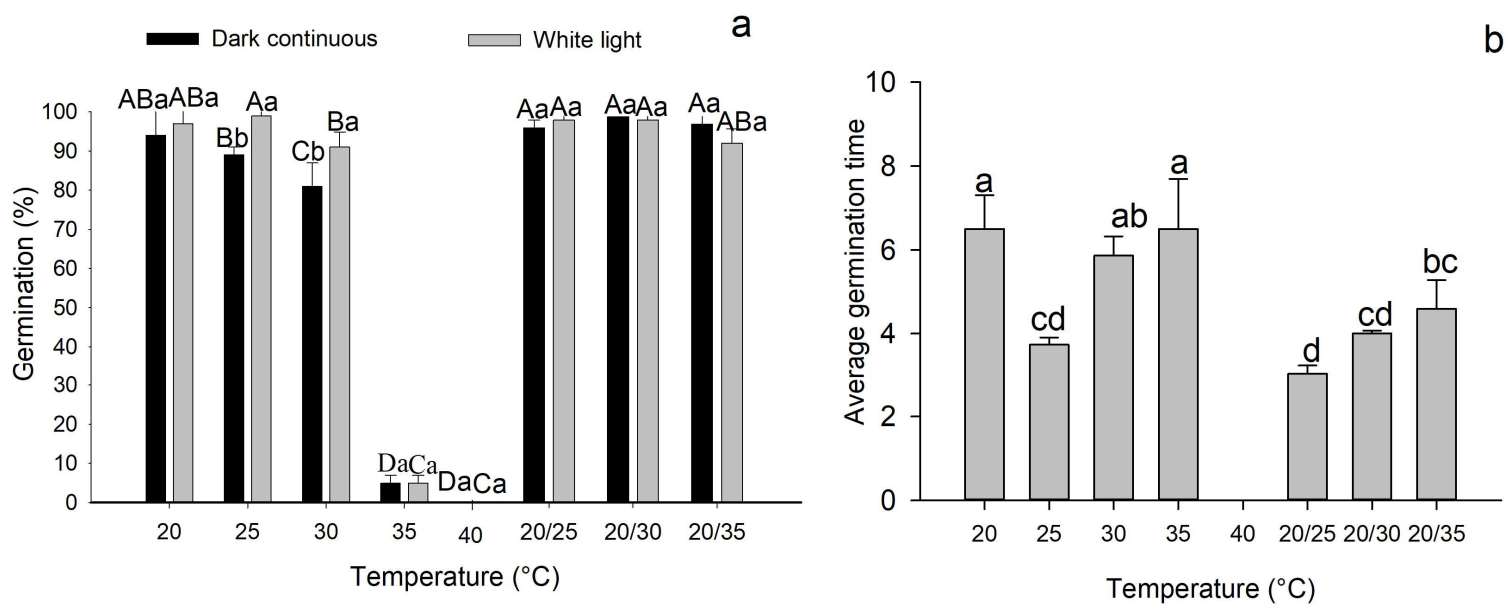

Figure 1: Germination (a) and average germination time (b) of Cryptostegia madagascariensis submitted to different temperatures and light intensity cycles. Columns represent the averages and bars represent error. $a$ : The temperatures are followed by the same lowercase letter and the same upper case between temperatures indicate no difference by the Tukey test $(p<0.05)$. $b$ : Means followed by the same lowercase letters do not differ by the Tukey test $(p<0.05)$. 
The two stress conditions, water and salt, significantly affected the variables studied in germination ( $\mathrm{p}<0.01)$. The percentage of germination was not affected until $-0.2 \mathrm{MPa}$. However, in salt stress the germination was completely inhibited at $-0.8 \mathrm{MPa}$ (Figure 2a) and in the water stress only at $-1.0 \mathrm{MPa}$ (Figure $2 \mathrm{~b}$ ). We also observed that for both types of salt concentration the seeds showed a high recovery capacity after 15 days when transferred to distilled water (Figure 2, a and $b)$.

The germination time was very sensitive to stress, as the addition of salt (PEG 6000 or $\mathrm{NaCl}$ ) to the substrate increased germination time at the lowest concentration $(-0.2 \mathrm{MPa})$. In the control treatment, germination occurred at four days, while in the presence of salt, germination time was greater than seven days (Figure 2, $\mathrm{c}$ and d).
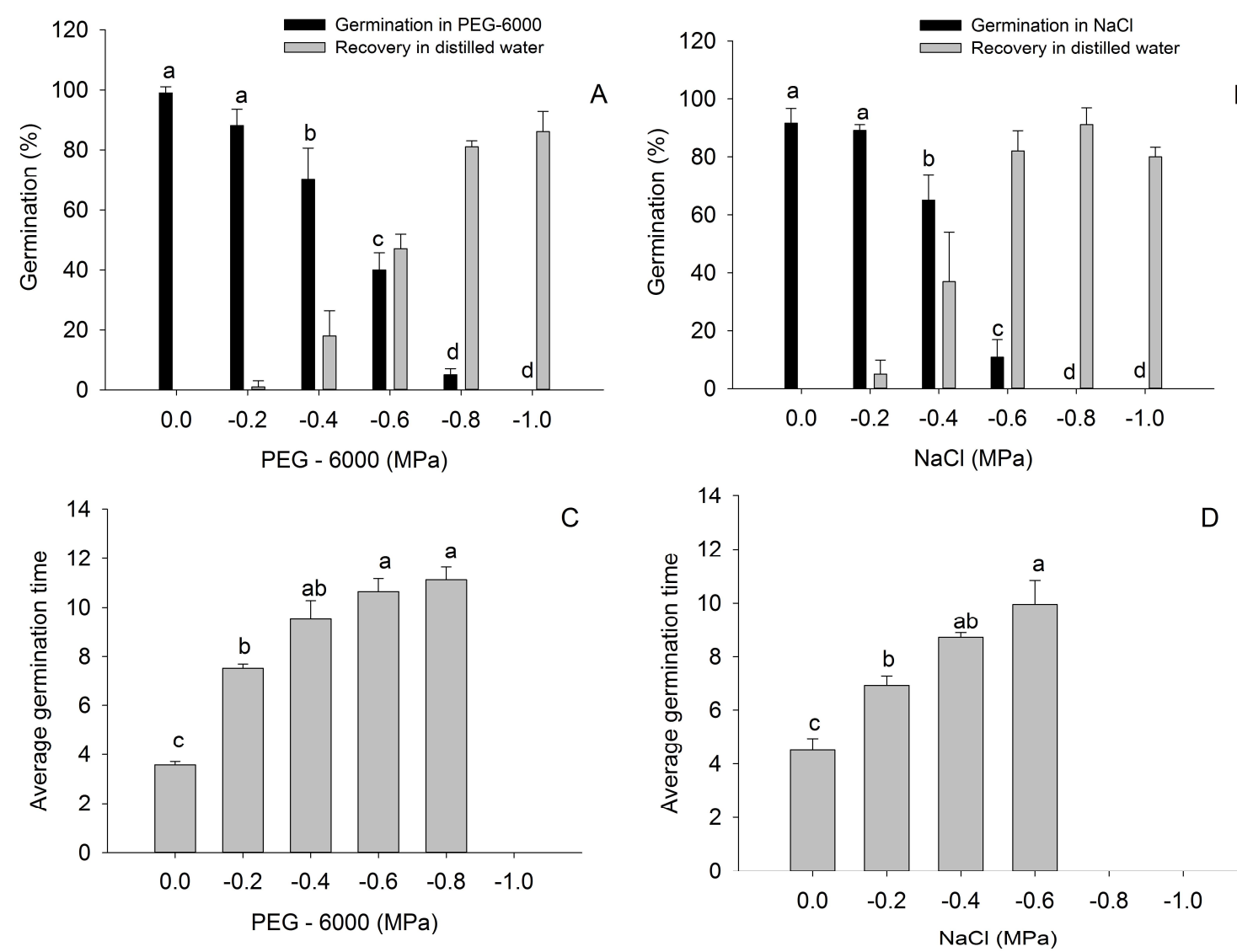

Figure 2: Germination ( $a$ and $b$ ), recovery ( $a$ and $b$ ) and average germination time ( $c$ and $d$ ) of Cryptostegia madagascariensis submitted to water stress (PEG-6000) and salt (NaCl). Columns represent averages and bars represent error. Means followed by the same lowercase letters do not differ by the Tukey test $(p<0.05)$.

\subsection{Initial growth in water deficit}

During the initial growth, none of the seedlings died in the water deficit treatments. The results also showed that the reduction of water availability had a significant effect on all variables studied $(\mathrm{p}<0.05)$ except for the root length, which was not affected (Table 1). 
Table 1: Averages and $F$ values for morphological characteristics of Cryptostegia madagascariensis growing at different water levels. RGR-relative growth rate; SLA-specific leaf area; SRG-specific root growth; $R / S$ - mass Root/shoot ratio; TDM- total dry mass.

\begin{tabular}{|c|c|c|c|c|c|}
\hline \multirow[b]{2}{*}{ Features } & \multicolumn{4}{|c|}{ Stress Level } & \multirow[b]{2}{*}{$F$ values } \\
\hline & $\begin{array}{l}\text { Absence } \\
(100 \%)\end{array}$ & $\begin{array}{l}\text { Low } \\
(70 \%)\end{array}$ & $\begin{array}{l}\text { Moderate } \\
(40 \%)\end{array}$ & $\begin{array}{l}\text { Severe } \\
(10 \%)\end{array}$ & \\
\hline Height $(\mathrm{cm})$ & $56.15 \mathrm{a}$ & $57.02 \mathrm{a}$ & $57.02 \mathrm{a}$ & $18.87 \mathrm{~b}$ & $581.64 * *$ \\
\hline Diameter (mm) & $4.87 \mathrm{a}$ & $4.58 \mathrm{a}$ & $4.61 \mathrm{a}$ & $2.58 \mathrm{~b}$ & $13.49 * *$ \\
\hline RGR ( g g $^{-1}$ dia) & $0.03 \mathrm{a}$ & $0.03 a$ & $0.02 b$ & $0.006 \mathrm{c}$ & $32.22 * *$ \\
\hline Number of leaf & $21.75 \mathrm{a}$ & $20.16 b$ & $19.16 \mathrm{~b}$ & $3.99 \mathrm{c}$ & $484.01 * *$ \\
\hline Leaf area $\left(\mathrm{cm}^{2}\right)$ & $360.26 \mathrm{a}$ & $314.27 \mathrm{~b}$ & $238.07 \mathrm{c}$ & $73.08 \mathrm{~d}$ & $450.02 * *$ \\
\hline SLA $\left(\mathrm{cm}^{2} \mathrm{~g}^{-1}\right)$ & $236.07 b$ & $159.46 \mathrm{c}$ & $198.47 b c$ & $289.94 \mathrm{a}$ & $10.76^{* *}$ \\
\hline Root length $(\mathrm{cm})$ & $64.62 \mathrm{a}$ & $58.50 \mathrm{a}$ & $64.43 \mathrm{a}$ & $60.63 a$ & $3.10^{\mathrm{ns}}$ \\
\hline SRG (cm g) & $43.04 \mathrm{~b}$ & $35.08 \mathrm{~b}$ & $50.29 \mathrm{~b}$ & $90.56 \mathrm{a}$ & $10.00 *$ \\
\hline$R / S(g)$ & $0.38 \mathrm{~b}$ & $0.42 \mathrm{~b}$ & $0.49 \mathrm{~b}$ & $1.28 \mathrm{a}$ & $128.97 * *$ \\
\hline TDM (g) & $4.71 b$ & $5.60 \mathrm{a}$ & $3.88 \mathrm{c}$ & $1.18 \mathrm{~d}$ & $218.81 * *$ \\
\hline
\end{tabular}

Means followed by the same letter do not differ by Tukey test. $*(\mathrm{p}<0.05) ; * *(\mathrm{p}<0.01) ;{ }^{\text {ns }}$ Not significant.

Seedling height was affected only by severe stress treatments. During the experiment, plants exposed to low or moderate stress levels reached more than $55 \mathrm{~cm}$ in height, and reached less than $19 \mathrm{~cm}$ under severe stress. Stem diameter was lower in the high stress treatment group but did not differ between the other treatments. We observed that the RGR of the seedlings was negatively affected in all treatments with water reduction, being lower under severe stress (Table 1). Was observed that the seedlings that received severe stress treatments experienced a loss of leaves. We also found no difference between leaf numbers at low and moderate stress levels. In relation to the leaf area, it was decreasing with the reduction of water availability, resulting from both the formation of smaller leaves and the loss of leaves (Table 1).

The SLA of C. madagascariensis was higher in the treatment of severe stress and lower in low and moderate stress. For root investment, we observed that root length was not affected by the availability of water. However, the seedlings that received the severe stress treatment showed a higher RSG and R/S ratio. The total dry mass of seedlings was lower in severe stress and higher in the treatment of low stress (Table 1).

In relation to the biomass allocation to the different organs, we observed that the seedlings that received severe stress allocated a greater proportion of biomass to the roots $(50 \%)$. Considering the two intermediary stress levels, we found a similar allocation ratio between root and stem. On the other hand, in the absence of stress the largest mass was allocated to the stem, 41\% (Figure 3).

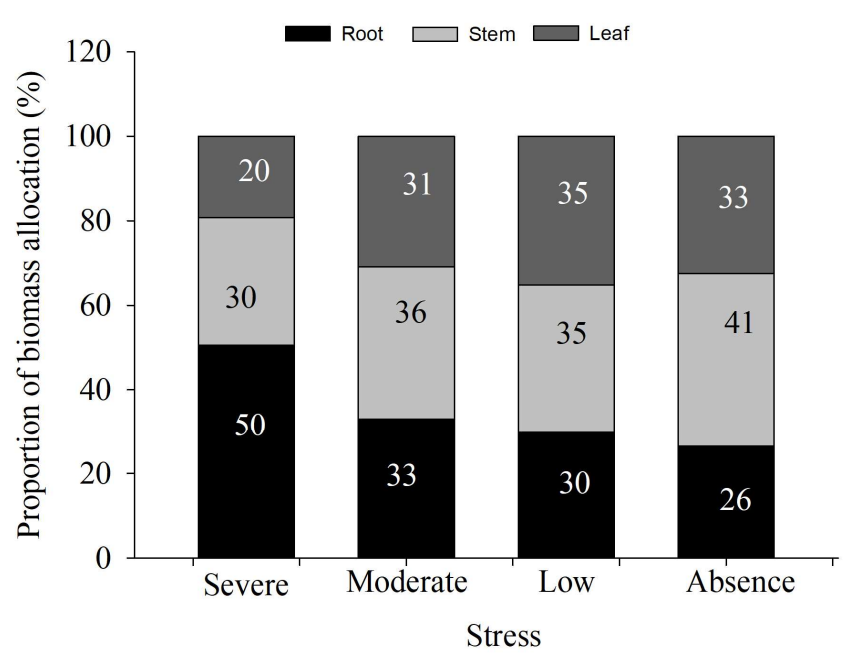

Figure 3: Proportion of biomass allocation between the different organs of Cryptostegia madagascariensis growing at four levels of stress. 
The regression analysis of the growth variables showed that the increase in leaf area explains at least $86 \%$ of the accumulation of dry matter in the seedlings (Figure $4 \mathrm{a}$ ). The increase of the leaf area is also related to a higher RGR, 74\% (Figure 4b).

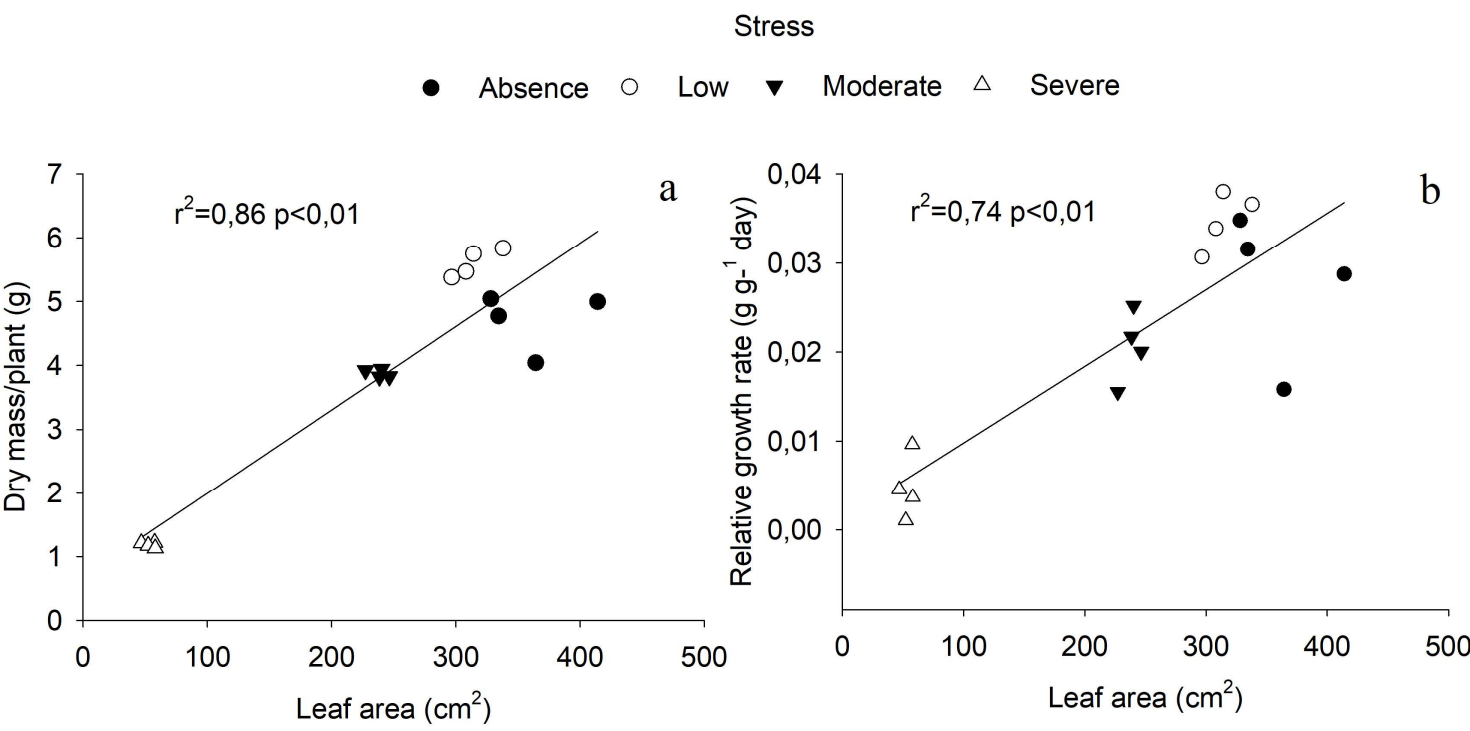

Figure 4: Regression analysis between leaf area and total dry mass (a) and leaf area and relative growth rate (b) of Cryptostegia madagascariensis growing at four stress levels.

\section{DISCUSSION}

The invasive potential of C. madagascariensis can be directly associated with high reproduction rates [20] and rapid and high germination, in addition to germination independent of light. We also observed that adaptations to declines in water availability can guarantee the survival of seedlings of this invader in low water levels, which can occur even in riverine areas of the semiarid [29]. On the other hand, high temperatures, and saline and water stresses can inhibit their germination. In addition, reducing water availability reduces seedling growth during the initial establishment, and can be a determining factor for the invasiveness of this species in the semiarid region of Brazil.

Seeds of $C$. madagascariensis germinate rapidly when water availability and temperatures are adequate, with an average germination time of four days at temperatures of $25,20 / 25$ and $20 / 30^{\circ} \mathrm{C}$. According to Abreu e Garcia (2005) [30], rapid germination is an important ecological strategy, enabling seedlings to take advantage of favorable environmental conditions. These authors also affirm that the average germination time also indicates the speed with which a species is able to colonize a new environment. Therefore, the rapid germination of $C$. madagascariensis allows it to rapidly colonize a new area when it offers suitable abiotic conditions.

On the other hand, high temperatures constitute a barrier to germination, becoming very low or absent above $30^{\circ} \mathrm{C}$. In addition, when germination occurred, the mean time was higher at about 7 days. According to Baskin e Baskin (2014) [9], the absence of germination at elevated temperatures may be a survival strategy, so that seedlings are not exposed to unfavorable conditions.

Light is not a fundamental resource for the germination of $C$. madagascariensis, although at temperatures of 25 and $30^{\circ} \mathrm{C}$ the absence of light reduced germination. Viera et al. (2004) [20], also studied the germination of $C$. madagascariensis, light reduction percentages, and the formation of normal seedlings. Thus, environments with more light availability should increase their germination, which may help to explain the higher rate of occurrence of this invader in disturbed areas as observed by Sousa et al. (2016) [31]. However, the germination of $C$. madagascariensis occurs at different temperatures and light availability, which shows that this species is able to colonize environments with different climatic conditions, such as under the canopy and in open areas. 
The seeds of $C$. madagascariensis are very sensitive to water and saline stress. Small concentrations of the salts PEG 6000 and $\mathrm{NaCl}$ reduced the percentage and increased the time to germination. According to McDonald (2007) [32] and Ramirez et al. (2014) [33], decreased water availability may inhibit the mobilization of reserves, respiration, and enzymatic activity in seeds. Although water and saline stress may inhibit the germination of $C$. madagascariensis, the seeds maintain viability and high germination rates when transferred to distilled water, reaching similar percentages to those observed in the control treatments. Pujol et al. (2000) [34] found that low osmotic potential is a factor that can induce dormancy (inhibition of germination until favorable conditions) in seeds. According to Khan et al. (1998) [35], this may occur through compounds that inhibit germination.

Therefore, the ability of $C$. madagascariensis seeds to remain viable under conditions of high stress and to germinate when these conditions are overcome shows that these factors do not affect their viability. Gorai et al. (2009) [25], observed that Diplotaxis harra (forssk.) boiss, an invader from the arid region of Tunisia, also presents a high capacity for recovery of germination after stress. Thus, this characteristic may be a strategy to colonize and invade semi-arid regions, which are more subject to drought and saline conditions [36].

As expected, water is one of the most important resources for the invasive potential of $C$. madagascariensis, since it negatively affects the germination and initial growth of the seedlings. Low water availability resulted in changes in most of the morphological characteristics assessed during initial growth, many related to adaptations to stress conditions. The reduction in the number of leaves and leaf area observed in C. madagascariensis reduces perspiration surfaces and the loss of water [37, 15]. Our results showed that the reduction of leaf area occurred during low stress conditions, and in severe stress we observed the loss of leaves in seedlings. Brown et al. (1998) [38] verified that the invasive congener $C$. grandiflora is a decidua optional according to the availability of water. Therefore, the loss of leaves by $C$. madagascariensis under conditions of higher water stress may indicate that the formation of a dense canopy on native species is related to areas with increased water availability.

The reduction of RGR under moderate stress conditions can be an advantageous strategy for invasive plants in arid environments, as according to Rejmánek (2011) [4], high growth rates demand higher water consumption. In addition, the treatment of low stress induced an increase in productivity (TDM) of the seedlings of C. madagascariensis. According to Morais e Freitas (2012) [16], this higher growth in low levels of stress can occur so that seedlings can take advantage of the available water. In the seedlings that grew under moderate stress levels, we observed only leaf changes (leaf area and SLA lower) and shoot growth. While during severe stress the seedlings presented more extreme signs of dehydration, such as loss of leaves and changes in roots. Even with lower water availability, the seedlings showed growth of the root system. According Farooq et al. (2009) [15] and Drenovsky et al. (2008) [28], the seedlings can increase the uptake of soil resources through a higher root/ shoot ratio. In addition, under severe stress, the seedlings presented a high RSG, which indicates the production of thinner roots at a lower cost to the plant and also increases the area of absorption $[39,40]$.

The observed morphological changes contribute to the survival of $C$. madagascariensis under conditions of a water deficit. However, they may conflict with the invasiveness of this species, since the invading potential of climbing plants is associated with high productivity [17] through large leaf areas and high photosynthetic rates [41]. We observed that RGR and the total dry mass of C. madagascariensis are directly related to the increase of leaf area. Therefore, the production of smaller leaves and the loss of leaves when water availability is low reduces the growth capacity of this invader. Thus, it is expected that the formation of dense coverings of $C$. madagascariensis, high growth, and the ability to scale the nearby vegetation are associated with areas of high humidity, such as the rivers and areas of $C$. prunifera.

Finally, we can say that the high germination rates under different abiotic conditions is a factor associated with the invasive potential of this species. Therefore, control measures must be taken to prevent its reproduction. In addition, during initial growth the seedlings tolerate different water availabilities. However, we believe that $C$. madagascariensis seedlings can be successfully established in environments with a moderate degree of water stress, and conditions of greater stress should limit their expansion. From these results, mechanical measures of control for this invader should be adopted during the driest periods, as it may be most vulnerable. We also recommend 
more studies that include other abiotic variables and the tolerance of plants to drought over longer periods of time.

\section{CONCLUSION}

High temperatures $\left(>30^{\circ} \mathrm{C}\right)$, salt and water stress reduce their germination potential. However, germination is not affected by light availability. During initial growth, reduced availability of water affects its growth and leaf development, which may reduce its competitive capacity.

Finally, we can say that the high germination rates under different abiotic conditions is a factor associated with the invasive potential of this species. Therefore, control measures must be taken to prevent its reproduction. In addition, during initial growth the seedlings tolerate different water availabilities. However, we believe that $C$. madagascariensis seedlings can be successfully established in environments with a moderate degree of water stress, and conditions of greater stress should limit their expansion. From these results, mechanical measures of control for this invader should be adopted during the driest periods, as it may be most vulnerable. We also recommend more studies that include other abiotic variables and the tolerance of plants to drought over longer periods of time.

\section{REFERENCES}

1. Hejda M, Pyšek P. What is the impact of Impatiens glandulifera on species diversity of invaded riparian vegetation? Biol Conserv. 2006 Out;132(2):143-152, doi: 10.1016/j.biocon.2006.03.025.

2. Ricciardi A, Hoopes MF, Marchetti MP, Lockwood JL. Progress toward understanding the ecological impacts of nonnative species. Ecol Monogr. 2013 Aug;83(3):263-282, doi: 10.1890/13-0183.1.

3. Richardson DM, Pyšek P. Naturalization of introduced plants: ecological drivers of biogeographical patterns. New Phytol. 2012 Sep;196(2):383-396, doi: 10.1111/j.14698137.2012.04292.x.

4. Rejmánek M. Invasiveness. In: Simberloff D, Rejmánek M, editors. Encyclopedia of biological invasions. California: University of California Press; 2011. p. 680-684.

5. Zenni RD, Lamy JB, Lamarque LJ, Porte AJ. Adaptive evolution and phenotypic plasticity during naturalization and spread of invasive species: implications for tree invasion biology. Biol Invasions. 2014 Nov;16(3):635-644, doi: 10.1007/s10530-013-0607-8.

6. Funk JL. The physiology of invasive plants in low-resource environments. Conserv Physiol. 2013 Nov;1(1):1-17, doi: 10.1093/conphys/cot026.

7. Skálová H, Havlíčková V, Pyšek P. Seedling traits, plasticity and local differentiation as strategies of invasive species of Impatiens in central Europe. Ann Bot. 2012 Nov;110(7):1429-38, doi: 10.1093/aob/mcr316.

8. Rejmánek M, Richardson DM. What attributes make some plant species more invasive? Ecology. 1996 Sep;77(6):1655-61, doi: 10.2307/2265768.

9. Baskin CC, Baskin JM. Seeds: ecology, biogeography, and, evolution of dormancy and germination. 2nd ed. San Diego (CA): Academic Press; 2014.

10. Funk JL, Vitousek PM. Resource-use efficiency and plant invasion in low-resource systems. Nature. 2007 Jan;446:1079-1081, doi: 10.1038/nature05719.

11. Thuiller W, Richardson DM, Pyšek P, Midgley GF, Hughes GO, Rouget M. Niche-based modelling as a tool for predicting the risk of alien plant invasions at a global scale. Global Change Biol. 2005 Dec;11(12):2234-2250, doi: 10.1111/j.1365-2486.2005.001018.x.

12. Milton SJ, Dean WRJ. Plant invasions in arid areas: special problems and solutions: a South African perspective. Biol Invasions. 2010 Mar;12(12):3935-3948, doi: 10.1007/s10530-0109820-x.

13. Cleverly JR, Smith SD, Sala A, Devitt DA. Invasive capacity of Tamarix ramosissima in a Mojave Desert Floodplain: the role of drought. Oecologia. 1997 Jun;111(1):12- 18, doi: 10.1007/s004420050202.

14. Poff B, Koestner KA, Neary DG, Henderson V. Threats to riparian ecosystems in Western North America: an analysis of existing literature. J Am Water Resour As. 2011;47(6):1-14, doi: 10.1111/j.17521688.2011.00571.x.

15. Farooq M, Wahid A, Kobayashi N, Fujita D, Basra SMA. Plant drought stress: effects, mechanisms and management. Agron Sustain Dev. 2009 Mar;29(1):185-212, doi: 10.1051/agro:200802.

16. Morais MC, Freitas H. The acclimation potential of Acacia longifolia to water stress: implications for invasiveness. Plant Sci J. 2012 Nov;196:77-84, doi: 10.1016/j.plantsci.2012.08.007. 
17. Harris CJ, Gallagher RC. Vines and Lianas. In: Simberloff D, Rejmánek M, editors. Encyclopedia of biological invasions. California: University of California Press; 2001. p. 680-684.

18. Klackenberg J. Revision of the genus Cryptostegia R. Br. (Apocynaceae, Periplocoideae). Adansonia. 2001;23(2):205-218.

19. Silva JL, Barreto RW, Olinto L, Pereira OL. Pseudocercospora cryptostegiae-madagascariensis sp. nov. on Cryptostegia madagascariensis, an exotic vine involved in major biological invasions in Northeast Brazil. Mycopathologia. 2008 Apr;166(2):87-91, doi: 10.1007/s11046-008-9120-5.

20. Vieira MF, Leite MSO, Grossi JAS, Alvarenga EM. Biologia reprodutiva de Cryptostegia madagascariensis Bojer Ex Decne (Periplocoideae, Apocynaceae), espécie ornamental e exótica no Brasil. Bragantia. 2004 Dec;63(3):325-334, doi: 10.1590/S0006-87052004000300002.

21. Moro MF, Macedo MB, Moura-Fé MM, Castro ASF, Costa RC. Vegetação, unidades fitoecológicas e diversidade paisagística do estado do Ceará. Rodriguésia. 2015;66(3):717-743, doi: 10.1590/21757860201566305 .

22. Labouriau LG, Valadades MEB. On the germination of seeds Calotropis procera (Ait.) Ait.f. An Acad Bras Ciênc. 1976;48(2):263-284.

23. Michel BE, Kaufmann MR. The osmotic potential of polyethylene glycol 6000. Plant Physiol. 1973 May;51:914-916, doi: 10.1104/pp.51.5.914.

24. Salisbury FB, Ross CW. Plant physiology. 4th ed. Belmont (CA): Wadworth; 1991.

25. Gorai M, Tlig T, Neffati M. Influence of water stress on seed germination characteristics in invasive Diplotaxis harra (forssk.) boiss (brassicaceae) in arid zone of Tunisia. J Phytol. 2009 Sep;1(4):249-254.

26. Souza CC, Oliveira FA, Silva IF, Amorim Neto MS. Avaliação de métodos de determinação de água disponível e manejo da irrigação em terra roxa sob cultivo de algodoeiro herbáceo. Rev Bras Eng Agríc Ambient. 2000 Sept/Dec;4(3):338-342, doi: 10.1590/S1415-43662000000300006.

27. Poorter L. Growth responses of 15 rain-forest tree species to a light gradient: the relative importance of morphological and physiological traits. Funct Ecol. 1999 Jun;13(3):396-410, doi: 10.1046/j.13652435.1999.00332.x.

28. Drenovsky RE, Martin CE, Falasco MR, James JJ. Variation in resource acquisition and utilization traits between native and invasive perennial forbs. Am J Bot. 2008 Jun;95(6):681-687, doi: 10.3732/ajb.2007408.

29. Smith SD, Devitt DA, Sala A, Cleverly JR, Busch DE. Water relations of riparian plants from warm desert regions. Wetlands. 1998;18:687-696, doi: 10.1007/BF0361683.

30. Abreu MEP, Garcia QS. Efeito da luz e temperatura na germinação de sementes de quarto espécies de Xyris L. (Xyridaceae) ocorrentes na Serra do Cipó, MG, Brasil. Acta Bot Bras. 2005;19(1):149-154, doi: 10.1590/S0102-33062005000100014.

31. Sousa FQ, Andrade LA, Xavier KRF. Cryptostegia madagascariensis Bojer ex Decne.: impactos sobre a regeneração natural em fragmentos de caatinga. Agrária. 2016;11(1):39-45, doi:10.5039/agraria.v11i1a5357.

32. McDonald MB. Seed moisture and the equilibrium seed moisture content curve. J Seed Sci. 2007;29(1):7-18.

33. Ramirez AHM, Jhala AJ, Singh M. Factors affecting germination of Citronmelon (Citrullus lanatus var. citroides). Weed Science. 2014 Mar;62(1):45-50, doi: 10.1614/WS-D-13-00041.1.

34. Pujol JA, Calvo JF, Ramírez-Díaz L. Recovery of germination from different osmotic conditions by four halophytes from Southeastern Spain. Ann Bot. 2000 Feb;85(2):279-286, doi: 10.1006/anbo.1999.1028.

35. Khan MA, Ungar IA, Gul B. Action of compatible osmotic and growth regulators in alleviating the effect of salinity on the germination of dimorphic seeds of Arthrocnemum indicum L. Int J Biol Sci. 1998 Mar;159(2):313-317, doi: 10.1086/297552.

36. Dirzo R, Young HS, Mooney HA, Ceballos G. Seasonally Dry Tropical Forests Ecology and Conservation. United States of America: Island Press; 2011.

37. Namirembe S, Brook RM, Ong CK. Manipulating phenology and water relations in Senna spectabilis in a water limited environment in Kenya. Agroforest Syst. 2009;75:197-210, doi: 10.1007/s10457-0089169-7.

38. Brown JR, Scanlan JC, McIvor JG. Competition by herbs as a limiting factor in shrub increase: a test with different growth forms. J Veg Sci. 1998 Dec 9(6):829-836, doi: 10.2307/3237048.

39. Withington JM, Reich PB, Oleksyn J, Eissenstat DM. Comparison of structure and life span in roots and leaves among temperate trees. Ecol Monogr. 2006 Aug;76(3):381-397, doi: 10.1890/00129615(2006)076[0381:COSALS]2.0.CO;2.

40. Cornelissen JHC, Lavorel S, Garnier E, Díaz S, Buchmann N, Gurvich DE, Reich PB, Ter Steege H, Morgan HD, Van Der Heijden MGA, Pausas JG A, Poorter H. A handbook of protocols for standardized and easy measurement of plant functional traits worldwide. Aust J Bot. 2003 Jan;51(4):335-380, doi:10.1071/BT02124. 
41. Paul GS, Yavitt JB. Tropical vine growth and the effects on forest succession: a review of the ecology and management of tropical climbing plants. Bot Rev. 2011 Mar;77(1):11-30, doi: 10.1007/s12229-0109059-3. 